\title{
THE RHETORIC OF GRAECO-ROMAN EROTIC LOVE VERSUS EARLY CHRISTIAN RHETORIC
}

Vossie Vorster

University of South Africa

\begin{abstract}
Foucault, Veyne and others have indicated that early Christian morality was firmly embedded in the Graeco-Roman ethos and should not be regarded as unique. The article elaborates, using the notion of the "regulatory body," expressed in terms of Laquer's "one-sex model" to show how rhetorics of love were determined by the body politic of the "regulatory body," entrenching, empowering and confirming societal structures. It is argued that early Christianity's rhetoric foists upon the terminologies of Graeco-Roman erotic love, radicalising these terminologies by interiorisation.
\end{abstract}

Keywords: Rhetoric of the Body, Rhetoric of Sexuality, Regulatory Body, Graeco-Roman Lovemaking, Erotic Love, Early Christian Lovemaking, Early Christianity and Sex, Early Christian Patriarchy

\section{Introduction}

Human desire, that mysterious and most intimate bodily force which we simultaneously crave and fear, flooding our selves, moving us between pleasure and pain, is socially constructed and subject to political manipulation. In his "argument" to the fragment "Show Me Whom to Desire" Barthes (1978, 136) writes: "The loved being is desired because another or others have shown the subject that such a being is desirable: however particular, amorous desire is discovered by induction." In his elaboration of the argument he continues: "This "affective contagion," this induction proceeds from others, from the language, from books, from friends: no love is original. (Mass culture is a machine for showing desire: here is what must interest you, it says, as if it guessed that men [sic] are

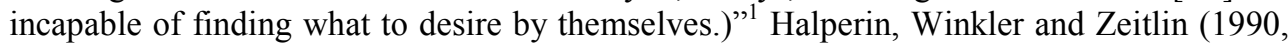
4) have coined the term a "cultural poetics of desire," signifying the interrelated configurations of social meaning within which sexuality should be seen. With this term they refer to behavioural conventions, social distinctions, conceptual schemes, aesthetic values, religious attitudes, moral codes, gender roles, and paradigms of sexual excitement and they submit that this conglomeration of social aspects and tensions function as a process including the formation of sexual identity. In a context different from lovemaking and desire Butler $(2004,45)$ expresses it more concisely: "At the most intimate levels, we are social: We are comported towards a "you"; we are constituted in the cultural norms that precede and exceed us, given over to a set of cultural norms and a field of power that condition us fundamentally."

The concern of this essay is to look at the manner in which that most intimate sphere of human interaction, namely human desire for an "other" and its expression in the sexual act,

See in this respect also Armstrong (2002, 20-31) in which he indicates that despite our evolutionary predisposition towards love, love has a cultural history which determines the experience of love. 
has been regulated and subjected to serve the interests of body politics. The notion of "regulatory body" is used to concentrate what Barthes, Halperin, Butler and as will be seen, Foucault have provided as constituents of cultural and identity formation. I argue that the notion of a "regulatory body," product of powerful, discursive practices which formed over centuries, functions as the embodiment of generating principles, constantly reproducing regulatory mechanisms for the structuring of society. I submit that the notion of the regulatory body enables us to move away from the question whether early Christianity indeed "made a difference," whether continuity or a discontinuity between the GraecoRoman world and early Christianity can be seen. At the same it enables us to see how the rhetoric of lovemaking, gradually developing affection in the Graeco-Roman world, was appropriated by early Christianity to radicalise patriarchy, not only in its construction of myth, but also in its construction of social ethos and structures. The religious rhetoric of early Christianity foisted upon the rhetoric of lovemaking in the Graeco-Roman world and radicalised it to produce a cult striving towards ultimate manhood.

\section{Desire as Power, Residing in the Recessive Body}

Different deified personifications strive to express the power of desire, albeit not always without ambiguity which can at times be related to the particular political situation. Eros is usually equated with the mischievous, almost boyish love god who is responsible for both the joys, pleasures, but also woes and miseries of love. However, this portrayal of Eros happened during the Hellenistic period and was the product of a long development. The power associated with Eros can already be seen in what we have of his origins. Worshipped in very early times by the inhabitants of Thespiai in Boeotia as a god who cultivated such a degree of friendship among comrades at arms that it could produce true bravery and courage Eros initially acquired his power as a god of war protecting the prosperity of the state (Ely 2003 [1891], 188-191). By the time of Hesiod's Theogony, however, he has become one of the fundamental cosmic forces, "omnipotent over mortals and gods alike" (March 1998, 153). Present at the birth of Aphrodite, he was later also both her son and constant companion (see also Dover 2003 [1973], 114). Zeitlin (2002, 50) writes: "From the archaic period through the classical and Hellenistic ages and down to the end of antiquity, Eros is a continuing obsession that permeates the cultural fabric in different registers and in different modalities of expression." The representation of Eros as a mischievous youth with bow and arrow, sometimes as a little boy, should not detract from his power - as a matter of fact, that such a small boy may conquer the most courageous hero makes him the embodiment of a teasing irony (Ely 2003 [1891], 192; also Zeitlin 2002, 51).

Aphrodite is the female embodiment of desire and her domain covers every aspect of desire as can be seen in the term ta aphrodisia, translated as the "things of Aphrodite" (Dover 2003 [1973], 114; Zeitlin 2002, 65). In herself the epitome of female beauty, sexual attraction, and the allure of beauty, love and desire belonged to her sphere of power. Although various traditions exist tracing her origins, Aphrodite was seen as one of the 12 Olympian main deities and immensely powerful. Married to the crippled smith-god Hephaestus, her power is again confirmed in her constant love affair with the war-god Ares. However, her power was perhaps best illustrated in the way she could persuade to the transgression of boundaries. It was within her power to evoke loving relationships between mortals and gods, among gods themselves, and among mortals. The opening lines of the Homeric Hymn to Aphrodite reflects her omnipotence in the following manner: "Tell me, Muse, the deeds of golden Aphrodite, the Cyprian, who stirs up sweet desire in the god, and 
overcomes the tribes of mortal men, and the birds that fly in the air, and all the creatures that live on dry land and in the sea" (March 1998, 55). As embodiment of desire which transgresses boundaries, ${ }^{2}$ she often caused confrontation, conflict, battle. ${ }^{3}$ And when she was resisted or rejected, disastrous consequences always followed, compelling her victims to succumb and rendering them powerless. ${ }^{4}$ As such she was a power which consistently threatened order, a potency inclining towards chaos. When Aphrodite entered the life of a human being, the experience was one of "overpowering," overwhelming. Extreme powerlessness and vulnerability ensued in the face of such extreme, boundless power. There was obviously an ambivalence - the pleasure of desiring and being desired is in itself a positive force and a mechanism for empowerment, which also explains the immense popularity of Aphrodite, but Ely (2003 [1891], 184) reminds us that the Greeks "saw in their goddess of love rather the tyranny of passion which observes no limits, and destroys the happiness of man."

It would be quite possible to provide a survey of all the other Graeco-Roman deified personifications of desire, such as Venus who displayed almost exactly the same attributes as Aphrodite, ${ }^{6}$ and who with her lover, the war god Mars, were recognised as the ancestors of the Roman nation. ${ }^{7}$ Or one could point to the popular and most portrayed god Dionysius, driven insane by the jealous Hera, cured by Cybele, followed by the "cross-bodied" satyrs, sileni, maenads and nymphs, all caught up in the constant frenzy of intoxication and passion. Sufficient to realise how the power of desire merited divine personification, allowed for boundless uncontrollability and a complete ignorance and intolerance of boundaries. Sufficient to see how the power of desire may enter a community's demarcated sphere of the insane.

But why bestow divinity on passion? Why personify an urge, or lust and then infuse it with divine status? Why construct an entire universe of immortal beings with immense power, but all subjected to the emotion of desire? I submit that the motivation for making desire divine was socially and politically strategic, but at the same time related and derived from bodily experience. As a matter of fact, Graeco-Roman mythology and early Christian religious discourse should be located within bodily discursive practices. Despite the intense experience of desire or love as bodily, our sexual experiences have not avoided the socially regulating and producing mechanisms of the regulatory body. The mystery of the interior body becomes a site for configurations of meaning ranging from healthy to sick, from positive to negative, from good to evil.

Zeitlin (2002, 65-66) indicates that the most common term for sexual intercourse is mixis, which signifies the transgression of boundaries, and these boundaries are those between men and women, humans and gods, and humans and animals.

3 Her beauty competition with Hera and Athena, presided over and judged by Paris, eventually results in the Trojan War.

4 See for example her revenge in Euripides' Hippolytos on Hippolytos who resisted the Aphrodite smitten advances of Phaedra.

5 What Ely's intention was with the use of the word "man" can only be speculated upon, but seen within the context of the Greek world, it was probably indeed the happiness of men which was at stake, as will become clear.

6 The mythology of Aphrodite was incorporated in the person of Venus and via her son Aeneas who was fathered by the Trojan prince Anchises, she became one of the supreme goddesses of Rome (cf. March 1998, 396). Through her it became possible for the Romans to find their descendancy in the Greeks.

7 See Kellum (2003 [1997], 281-288) for the manner in which Venus, Mars, Aeneas, Romulus, the house of Iulus and especially Augustus and Julius Caesar were incorporated in the architecture of the Forums of Julius Caesar and Augustus. 
To understand the strategic potential which desire may have, to understand why divine status could be bestowed on to desire we need to digress for a brief moment and allow ourselves to ponder the observations made by Leder (1990). Leder distinguishes between an ecstatic and recessive body, the former signifying the body's capacities to engage with its environment, the latter referring to the interiority of the body. The distinction should not be seen as a dichotomy and the experience of desire may be a good example to illustrate the integration of ecstatic and recessive body. Constrained by the social construction of desire, desire is always relational - it originates within a context and presupposes an "other." And yet, in that interaction a bodily secretion of hormones takes place, producing affection and desire towards the "other." As my "self" interacts with my environment, a quick furtive glance at a person, may produce a particular mood or passion which may be so revealing, so exposing, so violent that I rather need to avert my eyes from meeting the eyes of the target of my desire. In a slightly different context Barthes $(1978,44)$ expresses the futility of concealing bodily responses. He writes: "I can do everything with my language, but not with my body. What I hide by my language, my body utters... My body is a stubborn child, my language a very civilized adult." What the word conceals, the body reveals.

It is exactly from its emergence from the inside of the body, or the recessive body that desire derives its power. The ecstatic body with which I interact with my environment is subject to my control. Our sensorimotoric system allows us a measure of control - if I do not want to gaze upon a desirable object, I can choose to shut my eyes; a healthy person can will to take a glass of wine. For our survival our senses enable us to perceive and to willingly act upon our contextual requirement (Leder 1990, 11-15). The recessive body does not allow for the same leeway in volition than the exterior body. There is a certain automaticity to the recessive body which takes control in the operation and functions of bodily processes (Leder 1990, 45-49). Owing to the automaticity of my body, I am for most of the time unaware of its processes and functions - to a certain extent it appears to be absent. As such, the recessive body has a "will" of its own - it is in control without any volitional attempt on my part. Touching the person I desire may still be a volitional act, but the secretion of hormones sequential to the act follows automatically, and I am completely unaware of its secretion until it emerges again in all kinds of (sometimes quite embarrassing) physical manifestations on the surface of the body, such as widened pupils, lubrication, erection, perspiration, all bodily processes which are not directly under my control. The capacity of the body to function automatically gives rise to what can be called the "disappearance" of the body (Leder 1990, 83-92). To put it differently: the automaticity of the body which functions as the dominant process in the disappearing of the body, simultaneously generates the possibility for the disappearing of the body, that is the appearing, the "presencing" of the body in an uncontrollable manner.

This resemblance of power is radicalised in the disappearing body, because here an awareness of the body emerges with such a force that it may assume a form of "foreignness" (77-79). This happens when the body is experienced as out of control, when it intervenes with such a disruptive force that it demolishes an awareness of time and space and demands that attention be paid to a particular experience. Pain may, for example, launch such a totalitarian onslaught that everything else disappears to the background while only that remains focal. Sexual desire floods the body with a force which reminds of an occupying power and it catapults the body into an appearance. The automaticity of the recessive body already reveals the quality of control, of the capacity of an "it can," despite functioning in the mode of depth disappearance. However, when the recessive body suddenly appears, it appears with the hegemony of an occupying force. 
Owing to the power of the disappearing body, appearing as a disruptive force, the distrust of the body, a belief in it as "the seat of deception" derives exactly from the disappearance of the body, that is from its emergence only at times of error and limitation (Leder 1990, 86). It is from this disappearance of the body, from its appearance as uncontrollable, as an alien presence, as rendering the "self" unable, discourse derives to restore order, balance and equilibrium, albeit order, balance and equilibrium as determined by the community. It is the uncontrollability of the recessive body, its capacity to transgress beyond the reaches of the conscious volitional, that gives rise to the construction of an Eros, an Aphrodite, a Venus, a Dionysius ...but also to a Holy Spirit, a Satan and his demon buddies. Discursive practices, whether that be of cultic, political, medical or educational nature, emerge as regulatory strategies, on the one hand as products of a regulatory body, but on the other hand simultaneously structuring and regulating the community. An epistemology comes into existence, not only for understanding and coping with the incapacity to control, but also to function as basis from which to generate regulations for control. To empower this discourse in an absolute sense, it is bestowed with divine power.

\section{Love and Lovemaking in the Graeco-Roman World}

Since Foucault (1978), various authors have argued that sexuality as a specifically, demarcated sphere of human behaviour, as an analysable field which can be isolated from other fields of social life is a contemporary construction and it would be possible to see this position as a consequence of Essentialism. Although in differing ways these authors have also indicated that sexuality is culturally produced, is contextual and contingent - despite the development of a scientia sexualis, sex does not simply exist as a biological fact, and sexuality is not simply independent from the social practices of societies. Erotic love, lovemaking, desire or "the things of Aphrodite," despite its intimacy, is socially and culturally determined. Halperin, Winkler and Zeitlin $(1990,4)$ write: "The erotic experiences of individual human beings are thus in our view artefacts that reflect in part the larger cultural poetics of the societies in which those individuals live" ... and in a different context Halperin (2003 [1990], 132) elaborates: "it [sexuality] represents the appropriation of the human body and of its erogenous zones by an ideological discourse" and he concludes "the social body precedes the sexual body" (2003 [1990], 150). ${ }^{8}$

Taking our cue from Halperin's "cultural poetics of societies" we can reformulate our objective as the construction of a "cultural rhetoric of desire" with as specific focus the "regulatory body." The notion of the "regulatory body" conveys not only cultural practices as sedimented product but also submits an inner dynamics of power, it expresses the persuasive force of the social body and allows for the discursive body as catalystic site for

8 Halperin, Winkler and Zeitlin $(1990,3)$ make a distinction between sex and sexuality, in which the former functions as natural fact and the latter as the cultural interpretation of the body's erogenous zones and sexual capacities. This distinction is aligned with a quotation from Henderson in which sexuality is seen as a "complex of reactions, interpretations, definitions, prohibitions, and norms ... in response to the fact of two biological sexes." In both a distinction is made between "fact" and "interpretation," but several problems persist. First, "fact" surely should be seen as a product of interpretation. Second, can we really at this stage still speak of two biological sexes, knowing a range of sexes can be determined between the allegedly two sexes, knowing that biology is not pure, pristine or natural, but should in itself be seen as ideological discourse? Dichotomies, such as sex versus sexuality, or sexuality versus gender, or natural versus cultural, cannot but retain empowered vestiges of Essentialism. See Foucault $(1978,152)$ for "sex" as a "complex idea that was formed inside the deployment of sexuality"; also Winkler $(1990,17)$ who under the by now wellknown heading of "For "Nature," read "Culture"“" argues that sex is not a natural fact, because "any imaginable configuration of pleasure can be institutionalized as conventional and perceived by its participants as natural." 
the production of culture. The objective of this section is to establish the conditions upon which the regulatory body in the Graeco-Roman world were constructed and to determine the appropriate constituting principles that determined the experience of erotic love.

Lovemaking involves an "other," but loving an "other," being attracted to an "other," desiring an "other," functions within the legacy of love practices which they have inherited and internalised. In the Graeco-Roman world what was normative and what was deviant in the construction of desire complied and conformed to "conventionally defined gender roles" (Halperin 2003 [1990], 132). Sexual attraction and desire were not based on anatomical difference, not on age, and not on what can be called personal sexualised identity - it was not simply an individual affair (see Zeitlin 2002, 52) but was based on status (see also Sutton 1992, 5). A general assymmetry can be established in which sexuality was not mutual or reciprocal, but polarising and hierarchical (140). ${ }^{9}$ Whether during the Archaic, Classical, Hellenistic or Roman period, lovemaking occurred within what Laquer (1990) called a "one-sex" model. The anatomy and functions of the female body were referred to in language designed for the male body. ${ }^{10}$ "Medical" discourse from Aristotle to Galen and Soranus adhered to the male body as the criterion for sexuality. Aristotle differentiated between the sexes, but his differentiation is not constituted by anatomical difference, but rather by a drive towards perfection. The male body has a defining capacity which constitutes fatherhood and this blurred the distinction between "real bodies" (1990, 31). This does not mean that the ancients did not perceive the differences in genitalia. Laquer $(1990,34)$ refers to the abundance of terminologies in both Greek and Latin ridiculing and joking about genitalia, but when serious reflection occurred concerned with the basis of sexual difference, the male body was the criterion. Differences between the sexes were not seen as incommensurable, but were judged in terms of hierarchy and degree.

Since hierarchy, and not difference determined the construction of desire, domination by the aristocratic freeborn male was the driving, legitimate force. Halperin (2003 [1990], 140) indicates that legitimate sexual relations for a Greek adult male was with statutory minors, such as women, boys, foreigners and slaves and his superior status could be expressed in the power to "initiate a sexual act," the "right to obtain pleasure from it" and "his assumption of an insertive rather than a receptive role." It was fundamentally a political act in which the active, the penetrator confirmed his personal status on the ladder of the hierarchy present in the Athenian polis. The penetrator, whether penetration occurred vaginal, anal or intercrural, posed no threat to the social order, but confirmed an engendered social hierarchy. As such, sex was a manly act and had to be conducted in a manly manner.

It is the "one-sex model" with the phallus as primary cultural signifier which should be seen as the regulatory body of the Graeco-Roman world which has developed over centuries. ${ }^{11}$ The "one-sex model" as expression of the regulatory body not only functioned as product, but also in a reproducing mode through images, sculptures, ornamental material, utensils and then also in written material such as philosophical writings, legislation, stories, and "medical" material. I will refer to some of these practices in showing how the phallus

9 See also Richlin (1992, xviii) who argues that inequity was the essential framework of ancient gender relations.

10 Following Galen women were seen to have the same genitals as men, but in inverted, imperfect form. Ovaries were seen as female orcheis, that is, testicles and neither was there "any technical term in Latin or Greek, or in the European vernaculars until around 1700 , for vagina as the tube or sheath into which its opposite, the penis fits and through which the infant is born" (Laquer 1990, 5).

11 See on the phallus as cultural signifier, Halperin (2003 [1990], 140). 
functioned as primary signifier. It is perhaps in the erotic images that we can clearly see how sexual desire served to maintain power relations and that anatomical difference played an insignificant role. As the body politics changed during the centuries, certain changes can be detected in the representations of the body, but the "one-sex model" with its insistence on the inferiority of the passive partner, the smaller "other" or the alien outsider continued right up to the time of Constantine.

In erotic vase-paintings of the Archaic period, the stereotypical body of the male, the "approved male figure" functioned as model, not only for male to male lovemaking but also for male to female. Hetairai often resembled the beautiful boy, that is, broad-shouldered and thin-hipped (Clarke 1998, 21). During this period the scene is usually that of the symposium or even the more orgiastically oriented komoi and the adult, freeborn male clearly functions as the active agent; not only are the women depicted as hetairai, or even as prostitutes but they are abused and debased, and subjected to violent acts (Clarke 1998, 20-21). It should be kept in mind that these hetairai were often (although not always) non-Athenians, which meant that it was not only the body of a woman abused but also a body of an outsider (Shapiro 1992, 57). Sutton $(1992)^{12}$ indicates that these vase scenes which portray male emotional self-expression, coincide with wine drinking and propagate male dominance and female submission. The preference for the portrayal of rear-entry positions, allowed the painters to represent women as sexual tools whose emotions were of no concern to their male penetrators. In some of the scenes painted in the kômos tradition, the impersonal was replaced by sheer hostility and abuse and degradation of prostitutes became the dominant theme $(1992,11)$. Erotic vase painting during this period, allowing, even encouraging a violent and aggressive objectification of women served to indicate to what extent a "one-sex model" regulated the inferior position of women reaffirming their lack of social position and status. The concomitant emergence of courting scenes, representing male to male sex in the context of pederasty with the expression of affection, the avoidance of sexual abuse, anal sex, fellatio and mutual masturbation, as well as the advocation of intercrural sex functioned to confirm a social hierarchy generated by the "one-sex model" and served at this stage to enhance the aristocratic ideal (Sutton 1992, 32; see also Shapiro 1992, 57).

During the Classical period the message for the population changed gradually. For the ideal state or polis, the household has now become a mechanism to ensure reproductivity and stability in terms of established power relations. As the basic socio-political unit of the polis, the household had to portray the superiority of Athenian power and citizenship. Pericles' law of citizenship (451/0) specified that only a marriage to an Athenian woman could produce legitimate children with full citizen rights (Sutton 1992, 24). And it is at this time that the Pericles of Thucydides asked the Athenians to "direct their lust, that most personal of emotions, toward their city and become its lovers" (1992, 33). Lovemaking became regulated by a mechanism designed for insider consolidation. To ensure the social role of the household, the iconography designed for prostitutes and pederasty was appropriated for a portrayal of how married life should be. The scene of the symposium was discarded and the female nude is either portrayed in the close vicinity of water or as part of a wedding ritual. Sutton writes: "Female sensuality has been domesticated brought

12 Sutton's $(1992,3,4)$ study is quite useful in terms of Rhetorical Criticism since he specifically analyses vase paintings as a medium of social communication, reflecting on the type of target audiences and associating vase painting with romance narratives in popular art. Touching on what are called the peitho and cathartic models $(1992,6)$, the effect of sexual representation on social formation forms the theoretical background for an enquiry into "how the popular, mass-produced genre (daily life) scenes on Athenian pottery of the sixth and fifth centuries B.C. helped the people (dêmos) of Athens acquire the sense of corporate identity that made possible the radical democracy of the fifth century" $(1992,7)$. 
in as a kind of Peitho to persuade the Athenian bride, and possibly her groom as well, of her proper sexuality" $(1992,24)$. And the divine assists in this act of persuading women to accept their sexual role and social position in Athenian society. Eros, sometimes represented as Erotes, who functioned previously in the sphere of pederasty and prostitution now enters the domestic sphere of the so-called respectable woman (1992, 26-27). The "one-sex model" did not disappear as regulatory body; in these represented wedding processions the male leads, the male takes possession, the male glances towards the female, who usually glances downwards and the wedding is to a large extent linked to the veil. The "one-sex model" is appropriated by the body politics of its day and if marriage becomes necessary to exclude the outsider in order to maintain group solidarity, desire will accordingly be regulated.

We jump to the time of Augustus. Augustus' programme of cultural renewal and selfpropaganda penetrated into the intimate relationships depicted by lovemaking. But it is again the "one-sex model" that functioned as generative principle. The phallus as primary cultural signifier still functioned as a constant reminder that a particular social hierarchy had to be maintained. Kellum (2003 [1997], 284-285) has indicated how it manifested itself in architecture, such as the Forum of Augustus in Rome, as "advertising" signs at lupanaria (brothels), also on house walls, baker's ovens, on their paving, in their public baths, at the fortress gateways, via lamps, doorbells and children's amulets which had to offer protection against the Evil Eye. Neither what couples were doing, nor their anatomical difference was of any significant importance. What mattered was their status and despite the fact that he introduced marriage laws to ensure the continuity of the aristocratic, freeborn Roman citizen, the criterion for a legitimate expression of sexual desire was neither sexual difference, nor the boundaries of marital life, but a freeborn male Roman citizen in the position of the active partner. Male to male lovemaking abounds on drinking vessels and male to female lovemaking is quite amply depicted on several artefacts.

Despite the occurrence of male to male lovemaking and male to female lovemaking where the outlines of marital relations cannot be discerned, there is little doubt that Augustus' policies concerning marriage revived and emphasised self-control as the order restoring mechanism of a "one-sex model."13 The invocation of the mos maiorum was a mechanism of resistance against excess; in order to make Rome great, sexual discipline had to be restored and relegated to the boundaries of married life. Joshel $(1992,120)$ writes: "The denial of the body to the self speaks the denial of social powers to others: a Roman's rule of his own body provides an image of Roman domination and a model of sovereignty of Roman over non-Roman, of upper class over lower, of master over slave, of man over woman and of Princeps over anyone else... In particular, the morality of control served Rome's new ruler. Augustus presented the required image of control and sacrifice; ... denial and the morality of control enabled his authority to be "implanted into subject's bodies in the form of a lack of overflowing"... Woman was to be returned to her proper place. Marriage was to be regulated by the state; women's sexuality was to form the images and establish the boundaries so necessary to secure Rome's domination of others and Augustus' structuring of power."

In both Greece and Rome therefore the "one-sex model" with its phallocentrism served to control desire, and the control of desire conforms to an ideology where an interrelationship existed between a control of the self, the control of the household and a control

13 For an excellent discussion of Augustus' marriage reforms see Jacobs (1999, 109-123). The laws applicable were: lex Iulia de maritandis ordinibus, lex Iulia de adulteriis and the lex Papia-Poppaea (Jacobs 1999, 110). 
of civic society. In both Greece and Rome there was a movement towards an inequal equality between the sexes and the mechanism of marriage was used to establish a union between household members which was meant to serve the integrity and stability of society. Whether it was the "self," the household or the city, the male version of sôphrosunê, was the structuring principle of phallocratic Graeco-Roman society. Goldhill $(1995,4)$ writes: "For the classical city, it implies a political, moral and sexual control over the destabilizing forces of desire ... for the female subject, sôphrosunê is associated with a chastity that is indicative of a female's proper place within the patriarchal household and polis. For the ancient moralists it becomes the defining characteristic of the proper role of the citizen." Lovemaking, even in the marriage bedroom was determined by self-control and by a particular decorum since to disobey the normative codes would have been to produce an inferior citizen (cf. also Brown 1988, 20-24). In analyses of the ancient Greek romance novels, Perkins argues that discourse associated with female chastity was extended to include the male rendering them both subservient to the social order (Goldhill 1995, 67).

It was during the Augustan period that the "Greek romance novels," with its "happy endings" (see Perkins (1995, 41-76), resulting in marriage, originated. Although these novels may appear to reflect the origins of the "happy romantic couple," they are in effect representations of a phallocratic structuring of society. Perkins $(1995,62)$ shows how personal desire played a restricted role in the three romances, Chariton, Xenophon and Achilles Tatius. Personal desire initiated love between the partners, but then society took over in their management of personal attachment and personal interest became subservient to societal interests. Citizens were told "to become lovers of one another in the interests of social concord" $(1995,62)$. Brown $(1988,16)$ writes: "By the beginning of the late antique period, however, the vast weight of Empire had ensured that the Roman ideal of marital concord had taken on a crystalline hardness: the married couple were presented less as a pair of equal lovers than as a reassuring microcosm of the social order." In these novels an interrelationship exists between the overwhelming force of desire which manifests itself in the attraction between two partners of opposite sex, sôphrosunê as an extolled virtue which functions as mechanism of desire-constraint, concordia as principle weaving its binding thread through marriage and city and marriage as fundamental and integral ingredient for civic society. Marriage became portrayed as a symbios, a living together (cf. Jacobs 1999, 116),${ }^{14}$ the product of Augustan ethos which could be summarised as a "union of a man and a woman, a partnership for life involving divine as well as human law" (Jacobs 1999, 113). But this union did not represent equality between the sexes - desire was to be controlled from the perspective of a civic society which had the phallus as primary signifier. Marriage was a social mechanism of power in which the hierarchical arrangement of the social body was extended into the conjugal union. The desired symbiosis of the social body ensuring stability and harmony received its expression within the marital relationship.

If the institutionalised position of marriage may be taken as a barometer for measuring the hierarchic interaction between the sexes during the first two centuries, there appears to have arrived an ameliorisation between the sexes during this period. Although the Augustan legislation must have had its effect by this time, the movement away from marriage as the contractual product of family heads, determining finances, hereditary issues, good citizenship and firm household control, that is, the movement away from an institution determined

14 He refers to Plutarch who distinguished between people who were simply "joined together" (these are couples who married for dowry or children - more or less similar to modern marriages among the affluent zealously maintaining "comfort zones"); couples cohabiting together, and then finally couples who love each other where a "together living" can be discerned. 
completely by economical, political and social forces has gradually taken place over a period of three centuries. The Augustan legislation was in that sense therefore not revolutionary, but it does serve as an indication of the atmosphere between the sexes during the first two centuries. Despite of the engendered hierarchy which was still the operating principle and despite the political performance of marriage as essential institutional ingredient for the harmonious operation of the civic body, gradual recognition was given to the constructive forces of desire. Maybe this is still too positively formulated. But there appears to have been a movement towards what Veyne has called an "internalized morality of the couple" $(1987,47)$. Expressions of sexuality have gradually been hedged within the confines of marriage. Whether one could speak of the arrival of the "happy couple" in the West is disputable, but the notion of companionship, a higher form of friendship gradually emerged.

This is the time when the younger Pliny could write to his wife's aunt, telling her about the "mutual happiness" of him and his wife, and could express the hope that it will "last for ever" and increase "day by day" (Pliny the Younger, Ep. 4.19). His passion for his wife is however best seen in the letters addressed to herself. The anguish, anxiety, fear and frustration which the absence of a beloved thrusts upon the lover can clearly be seen in his letters (see Ep. 6.4), just as his temporary relief and consolation in the reciprocity of the situation when she expresses her experience of his absence (6.7). There is a recognition of a "loss of control" as he finds his feet "carrying" him to her empty room and he emphasises this involuntarily move to her by the interpolation "a true word, carrying." His description of his lovesickness reminds of the power of the recessive body launching its attack of passion and desire (see Ep. 7.5; also Foucault 1986, 79). This is the time when a Plutarch must have availed himself of current love vocabularies depicting the matrimonial state as a site where an ethical union par excellence can be established through the performance of philosophy. Marriage can produce companionship and a friendship of a higher order. It is a site where Aphrodite, Hermes, Persuasion and the Graeces exert their influence because pleasure may derive from communication - the couple's desire must be elicited through persuasion and not in conflict or quarrelsomeness (Plutarch, Coniugalia Praecepta 138; see especially also Jacobs 1999, 115-117). The concordia of marriage, the companionship, partnership, conjugal union or resemblance of the "couple" between an aristocratic, elite, freeborn man and a woman can also be seen in the numerous artefacts and images from this period. From paintings displayed in the bedrooms of upper class married couples a "domestication of desire" can be seen in the affectionate, non-violent, erotic poses (Myerowitz 1992, 141-142), and these pictures did not only serve a representational function - they were not simply a reflection of titillating experiences - but also served an educational function $(1992,149)$. The message was one of "this is, how it should be."15

Marriage, however, was to a large extent, the prerogative of the elite, upper class. Augustan reforms were directly addressed at the Roman aristocracy and the arts of reading, philosophising, decoration whether paintings or mosaics were part of affluent lifestyle. Jacobs indicates how both the Augustan proscriptions against certain types of unions, as well as the Plutarchan ethical internalization should be seen as restricted to a particular

15 Clarke $(1998,107)$ distinction between decorative and instructive is problematic. He writes: "If there is a cultural construction of attitudes towards sex between men and women in the pictures, it is one of sophisticated appreciation-of their rich setting ... and of the unhurried pace of the couple's lovemaking. These are not images that "document" in any sense the acts of lovemaking that might take place in these rooms. Their role is decorative, not instructive or documentary." However, if these were only decorative we find ourselves very close to representation, something which Clarke also denies. Furthermore, in the social hierarchy of the Roman world, the decorative was instructive - the aesthetics of art subtly regulated by proposing amorous dalliance as a desirable situation. 
social sphere and concludes that " $[\mathrm{m}]$ arriage remains the elevated ethics of an upper-class family" $(1992,112-118)$. It is the Greek romances who deproblematise status and rank and function as a veiling of power and class $(1992,121)$. Yet the plots of the Greek romances were concerned with conjugal union, with marriage as a "happy ending," albeit not a distinctive feature of the upper class.

While institutionalised marriage may serve as a barometer of an amelioration between the sexes, the moral interiorisation discerned within the sphere of marriage, can also be seen in the display of erotic lovemaking on artefacts, which may or may not have functioned within the social setting appropriate to marriage. Clarke (1998) refers to the numerous remains of mass-produced Arretine ceramics during the Augustan and early Julio-Claudian period $(1998,75,108)$. Despite of its specific origin from the city of Arretium, its affordability allowed for its widespread distribution throughout the entire Empire $(1998,72,76)$. These Arretine ceramics were notorious for its explicit portrayal of sexual penetration. Yet the manner and style in which sexual intercourse was displayed was in terms of affection, tenderness and love. A distinctive feature was its balance of opposites, portrayed in the act of sexual coupling. Clarke $(1998,114)$ formulates it as "an equilibrium won through many different means, from the composition of the individual bodies to the juxtapostion of scenes." It was, as if it were suggestive of an emerging equilibrium between the lover and beloved. Whether the penetrated indeed experienced pleasure is difficult to gauge, but the women are portrayed as "dignified and perfectly coiffed" with clear indications of "signs of subjectivity" $(1998,114,116)$. Their widespread consumption shows that the Roman viewer viewed the portrayal of explicit sexuality as part of everyday life on a continuum with other amorous depictions. Since these artistic representations presuppose some kind of patronage before it would have been produced, it can be assumed that a different social attitude towards sexuality was emerging at least among some Romans $(1998,118)$. There was a moral attitude present in the world in which early Christianity emerged, which made the "blessings of Venus, the joys of sexual passion and release" publicly available through its explicit portrayal. Furthermore, a moral attitude was emerging, testing, feeling, slightly stirring the assymetrical engendered hierarchy of the social body, depicting the possibility of harmony and balance, of poise and posture, of dignity and tenderness through the sexual coupling of lover and beloved.

This emerging possibility towards gender symmetry, towards balance should not detract from the immense continuing power of the highly, hierarchic regulatory body. As a matter of fact, it is not even remotely possible to think in terms of equality, individuality, selffulfillment on the part of those excluded by freeborn, male aristocracy. Against a construction of gender roles in Roman society, advocating a particular "amelioration in the condition of women under the Roman Empire," Konstan (2000) has argued that the tropes of the hierarchical order were still retained. Whenever and wherever the "one-sex model" with its insistence on male domination and female subordination was threatened, strategies were designed to recontain it. If, for example, a woman was portrayed as having courage, that is, sharing a male virtue, the female rendering of "courage" would be in the passive, that is, amounting to the endurance of torture or oppression (Konstan 2000, 5). The role of the "active," the penetrator had to remain in the hands of the male.

The very same younger Pliny who was fraught with passion for his young wife, wrote to her aunt that she "has proved herself worthy of her father, her grandfather and you" (in that order), and that she is "highly intelligent and a careful housewife," and that "her devotion to me [Pliny] is a sure indication of her virtue." Her love for him is, according to himself, based neither on his age, nor his person, "but from my aspirations to fame." Social status 
still remains the source of sexual attraction. His letter reports how her love for him finds expression in the way she learns from him in different aspects of life (Pliny the Younger, Ep. 4, 19). It reflects the stereotyped role of the husband as the teacher of his wife, the one who cultivates her and introduces her to his circle of sophisticated friends (Brown 1988, 13-14). One should also not forget that it was the same younger Pliny who reported to Trajan how he had had two slave-women tortured to extract truth concerning the Christians from them (Pliny the Younger, Ep. 10, 96). Slaves and women were "bodily" categories available and suitable for torture on the basis of their inferior bodies - since they were regarded as incapable to withstand torture, Pliny's choice was stereotypical logical. In a similar manner does Plutarch in his advice to the married couple assign the husband a position of formal cause - he is to be held accountable for the manner in which he produces a wife. Women, on the other hand, are required to be obedient (Plutarch, Coniugalia Praecepta 6), be invisible in the absence of their husbands (9), should be the follower, should model her life, her feelings on to those of the husband (140). In Ovid's Ars Amatoria women are regarded as raw material and naturally more sexual. In his descriptions of the various sexual positions a woman may assume, the male viewer's gazing judgement becomes the criterion as he prescribes an aesthetic hierarchy of bodily parts the female has to make the best of her best (Myerowitz 1992, 136). Despite the fissure (to use a Butlerian expression 1993, 10) of an alternative consisting in more freedom for women, the "one-sexed" regulatory body remained dominant and in power. As such this alternative, "new," interiorised morality functioned as a mechanism by means of which the one-sexed regulatory body reproduced itself.

Marriage became the institutional locus for the regulation of desire, because it provided with stereotypical gendered roles. The implication is that sexual behaviour still occurred within the hierarchies determining social status and position. Within marriage, the woman was still under male control, and he was responsible for her further education and introduction to his circle of friends. The apparent sense of partnership and being a "couple" veiled the relations of power which nevertheless regulated marital conduct. The passion of personal desire, with its possibility of disruptiveness and unruly chaos, was regulated in terms of communal desire. ${ }^{16}$ Furthermore, it functioned as a signifier of social stability. Marriage was not subject to the immediacy of instant passion, but suggested enduring commitment and permanency. In the Greek romances, "constancy" was seen as the "moral centre of the novel" (Perkins 1995, 66), reflecting and regulating social order and stability. Finally, marriage was not an option for everybody in antiquity - it was a social strategy ensuring a particular social hierarchy and for that reason available for the wealthy, the aristocratic and elite.

Lovemaking then, was on the one hand determined by the "one-sex model," that is, the conventional practices which prevailed within a society with the phallus as primary signifier. The regulatory body represented a body politic in which the hierarchic principle generated a relationship of domination versus submission, active versus passive, and penetrator versus penetrated. Each and every phase of sex, whether the beginning of desire or orgasmic climax was defined in terms of the phallus belonging to the superior, aristocratic, free male. In the reproduction of engendered hierarchy, the social body ensured

16 Care should be taken with the distinction between personal and communal desire in Antiquity. The distinction should not suggest a form of Essentialism as if a pure, pristine, "natural" type of desire could have originated between partners. The genesis of desire is also culturally initiated and regulated, but communal desire refers to the specific regulation within marital boundaries and functions. 
its constancy, its permanency, stability and durability and confirmed and entrenched its control over the individual body.

While lovemaking was determined by the phallus as primary signifier, the female body, in particular the female recessive body, functioned significantly in the construction of desire. I have already indicated and argued (following the cue of Leder, 1990) that desire is to be located in the disappearance of the recessive body, that it is the forcefulness with which it makes its appearance which has given it such power that divine status was bestowed on it in antiquity. However, although Eros was portrayed as masculine, Aphrodite and later Venus were constructed as female. A strange ambiguity can be detected in the manner in which desire was constructed in the Graeco-Roman world. "Desire activates a certain paradoxicality,” says Zeitlin $(2002,55)$. Phallic aggression also means submission to another's control which means that the lover is both active and passive at the same time $(2002,55)$. Halperin $(2003$ [1990], 142) expresses this ambiguity differently by making a distinction between the principles that "structured sexual and social roles in classical Athens" and the "sensation of being in love." Taking the compelling normativity of these constructed principles into account, this sensation of being in love, would have been experienced as a loss of mastery, an enslavement to the beloved or desired. However, this "self-abandonment," this voluntary surrender could by virtue of the regulatory body's forcefullness be seen as a strategy of indulgence. Halperin's distinction between principles generating roles and sensations is problematic especially when the power of social constructions are taken into account. If he is correct in his main argument, namely that the social body preceded the individual body, the sensation of being in love would also have been regulated from and within the ambit of the social categories created. As such, a selfabandonment in a world where erotic love was made to signify status and was embedded in strategies of competition, an expression of the sensation to be in love would have been a counter-strategy.

The ambiguity concerning the construction of desire could hardly be resolved, and as such it posed a threat to the invulnerability of the phallic regime. However, in order to safeguard the austerity and control of the "one-sex model," the male construction of desire appropriated terminologies deriving from the female body which was already infused with inferiority and dysfunctionality. The disruptive power with which desire makes its appearance originates from the recessive body. It is consequently also the female recessive body which functioned as source for the construction of desire.

The absolute disruptive power with which the recessive body in its mode of dysappearance appeared located it in engendered discourse in which it was associated with the female body. Padel $(1992,100)$ takes her cue from fifth century tragedy when she shows how the interior of the body was constructed from Greek constructions of gender, specifically from what constituted the role of the female. First, it is possible to find instances where splánchna can be translated as "womb" or "reproductive organs" and although the latter is sometimes also used for men, it occurs more frequently in the reference to women. But second and more importantly, splánchna do the same things that are usually associated with females. To put it a bit differently, it functions in the same type of engendered terminological field, for example, splánchna can swell, because it is penetrable. There is the possibility that there can also be an outward flow, but the invasion of the external into the internal seem to dominate when thought is given to the innards. Coinciding with the penetrability of splánchna, is also its passivity; in fifth century Greek tragedy which portrays females on the receiving end, also constructed a picture of the innards which receives. There is yet another area that emphasises the engendered nature of 
the recessive body, (or, how female-speak functioned to understand the inside of the body). The underlying is again the relationship between "inside" and "outside." The female is associated with what is inside, the interior - she was supposed to be "inside" the house; that was her domain. But she is also continuously metaphorised in terms of the earth. The inside of the earth was on the one hand seen as consisting of "darkness," of dark flowing rivers; it is unseeable and at the same time both destructive and generative; it can nurture, when something is put into it, it can make things grow. It is at the same time also dark, chaotic, unruly and destructive. Padel $(1992,102)$ writes: "Greek notions of the femaleness interact with the basic Greek principle that the outer world, the kosmos, is made of the same fabric and structure as the inner. In male perceptions, women's inwardness merges the underworld, unseen recess of the world outside human beings, with the inner world, unseen recess within. Greek ideas of femaleness link the flux, darkness, magico-prophetic powers, and ... fertility of the innards with those of the underworld, earth and night."

The possibilities of disruption by the recessive body were increased in antiquity since what we would regard as normal bodily conditions were seen as modes of dysfunctionality. The recessive body can be characterised by a certain automaticity which does not necessarily reflect a dysfunctional status, such as hunger, thirst, fatigue, the sexual urge, reproductive cycle, the digestive process and others. Yet in the world of Antiquity these states/conditions signified and could be taken as indications of dysfunctionality. If a "normal" state of the body can be seen as a construction, an "abnormal" or "dysfunctional" bodily construction can also be a construction and can be subject to an increase of those things that make dysfunctional. But as even those bodily conditions that are seen as part and parcel of the automaticity of the recessive body, lie outside our control, outside our ability to properly and accurately manage, increasing the domain of dysfunctionality by infusing it also with the properly functional of the recessive body, means to increase the power of dysfunctionality. In a paradoxical fashion it is exactly the dysfunctionality of the recessive body that provides with its power. It is this power of the recessive body which taneously necessitated its control and the more power it gains, the more mechanisms of control have to be introduced. Because the female body was constructed as inherently dysfunctional, its power was such that it also contained a quality of uncontrollability.

"Medical" discourse on the essential ingredients of the female body and deriving from humoural theory (see Dean-Jones 1994, 46, 49, 56, 120) offered further support to substantiate and clarify the female body's inclination towards uncontrollability. Uncontrollability implies not recognising boundaries - it implies the transgression of boundaries and it is this transgression of boundaries which contains a threat for the civic order. Essential ingredients of the female body rendered her predisposed towards the transgression of boundaries and hence uncontrollable (Carson 1990, 135; 2002, 78). ${ }^{17}$ The female body in the Graeco-Roman world was seen to be both porous and moist. Porosity and moistness were seen to be the distinctive characteristics of the female body $(1990,137$ 139). Her porosity rendered her penetrable and open to invasions from outside; her moistness damaged her thinking and was primary responsible for her emotionality, the movement of her interiority. As essentially wet, women were seen to be unbounded, without boundaries $(1990,153 ; 2002,79)$. The desired condition of dry stability could, because of her physique, never be reached; a woman's recessive body was seen to be always cold and wet and because of this innate wetness always subject to liquefying assaults, such as tears, pity, jealousy, despondency, fear, rash impulses, gluttony, extravagance, instability of mood, drunkenness, but especially sexual desire $(1990,138 ; 2002$,

17 These two essays by Carson overlap extensively: the 2002 version appears to be the abbreviated one. 
81; also Dean-Jones 1994, 56-57). From her inherent moistness emerges female lewdness, her wantonness (Carson 1990, 139), inclination towards excess and her inability to masculine constructed sôphrosunê $(1990,142)$. The most devastating of all emotions is love which is a combination of liquescent effect and fiery heat (Carson 2002, 81).

From a recessive body consistently assaulted by liquefying onslaughts emerges a predisposition towards a particular type of sexual desire. Woman is seen to be possessed by sexual desire, insatiable and without boundaries. This is also the manner in which she was portrayed in the ancient sex manuals (Holt 1992, 106). ${ }^{18}$ While her sexuality is always uncontained and therefore a reason for shame, male sexuality can be controlled and need not be a concern of shame. Salomon $(1997,204)$ for example discusses Praxiteles' Aphrodite Knidia, and comments that the hand either pointing or covering her pubis in either way prevents seeing it. To a certain extent this sculpture symbolised the assymetrical nature of female construction of desire. Completely in the nude, yet self-conscious, with a hand focussing on her genital area, yet concealing, a quality of sexual humiliation accompanies the love goddess $(1997,204)$. The assymetrical can be seen in the sculpture of Hermes, who poses in heroic, unselfconscious, male nudity $(1997,204,205)$. Furthermore, owing to the porosity and moistness of the female recessive body, female desire was seen to be undifferentiated, open and directed to any man. Halperin (2003 [1990], 147) indicates that female desire was constructed as a somatic need, which emerged from the particular physiology of the female body "and it could be aroused ... by anyone (even a woman) with the proper phallic equipment."

Lovemaking in the Graeco-Roman world was therefore determined by the phallus as sexual signifier. Although variations may be detected as the body politics of different periods varied, the "one-sex model" remained as a producing product of the regulatory body. The hierarchic principle evoked by the regulatory body, making the phallus primary signifier, would not be deflected by uncontrollable force of desire. Although the construction of desire was done from a male perspective and although the "one-sex model" catapulted "man" as agent of desire construction, hierarchy was maintained by relegating desire to the dysfunctionality of the female recessive body. The strategy of constructing desire as property of the dysfunctionality of the female recessive body, opened a field of controlling possibilities within the "one-sex model." The problematisation of desire made its structuring possible - it became a means to an end, the stability of the civic order. Marriage was promoted as a social strategy - at the top of the hierarchic scale it functioned as a mechanism to regulate social order by the re-affirmation of male superiority and power.

\section{Early Christianity's Problematisation of the Penetration Model}

Early Christianity arrived on the scene when the Graeco-Roman world was moving into a new, interiorised morality. Although the phallus as primary cultural signifier still reigned supreme when early Christianity arrived on the scene, the early Christians could have availed themselves of discursive practices allowing for the emergence of an alternative morality. However, early Christianity appropriated the "one-sex model," not only as principle for the structuring of their communal system, but also for the construction of their belief system. The androcentric regulatory body, in its expression with the phallus as

18 Although these manuals were criticised, the critique was directed at the excessive immoderation displayed (Holt 1992, 92). That women were prone towards the excessive was, however, also one of the assumptions on which the regulatory body operated. See also Henry $(1992,259)$. 
primary signifier continued in early Christianity. Despite of the diversity in early Christianity, of which people such as Veyne $(1987,47)$ and Brown (1988) constantly reminds us of, the regulatory body of the Graeco-Roman world regulated unabated and unabashed the lovemaking of the early Christian communities. The uniqueness which earlier scholarship has attributed to early Christianity, as if the latter were the first to really insist on monogamy, sexual austerity, marital fidelity and sexual abstinence, claiming a pristine and purified sexual ethics, has been proved as ideologically flawed (Veyne 1987, 47; Brown 1988 and 1990, 480; Foucault 1986, 235-240, also 1997 [1982], 195-196, and 1999 [1978], 121). The principles upon which the "one-sex model" functioned remained the regulatory body which initiated and regulated the particular social mechanisms and power relations of early Christianity.

The phallus remained the primary communal signifier, by means of which sexual relations were structured. As a matter of fact, it would be possible to argue that early Christianity endorsed a more radicalised version of the "one-sex" regulatory body in their regulation of desire. Brown $(1987,263)$ refers to the manner in which Christian apologists of the $2^{\text {nd }}$ to the $3^{\text {rd }}$ centuries C.E. used the "exceptionality" of Christian sexual austerity as a criterion expressing their difference with the Graeco-Roman world. The historical irony is that this difference was a radicalised confirmation of trends within the Graeco-Roman world, an even perverse modification of a regulatory body's normativity. The "family" or household rhetoric of the Graeco-Roman world, generated by a phallocratic ethos, and functioning as a microcosm for the maintenance of the macrocosm of the civic body, also functioned as the framework in which this regulation of sexual behaviour took place, and this rhetoric functioned on different levels. The emerging "new, interiorised morality" with its construction of desire, allowing for the paradoxical possibility of status-determined-yetreciprocal lovemaking, of conjugal union, albeit structured by engendered hierarchy, its public encouragement towards balanced, harmonious, tender and affectionate lovemaking, albeit from male perspective, is viewed with suspicion from early Christians, even with resistance. But the suspicion and resistance were motivated by an almost fanatical phallic zeal towards self-control. The construction of desire is less an ethical union between two people, than a de-construction of desire, making desire undesirable. The interiorisation of morality is radicalised to an eradication of desire, Foucault's "care of the self," to a selfish care. If what mattered is exceptional self-control, the "other" does not really have to be considered - what is morally imperative is that the acquired social role has to be acted in the most exceptional manner. Since desire may strike with the overwhelming ferocity of a god or demon from the inside of the body, inward looking, knowing your inside, designing techniques and regimes to control the inside of the body became the means to ensure that the fate, allocated social role can successfully, even exceptionally being carried out.

Within the Graeco-Roman world during the Hellenistic period the regulatory concern was the control of desire. An example was Plato's Socrates, lying down with a young and beautiful boy in the person of Alcibiades without touching him (Foucault 1997 [1981], 183). A "desire" was constructed which recognised the power of the recessive body and the influence which the "other" may have on stimulation of desire, thereby giving recognition to its relationality. It was constrained and regulated by a hierarchic principle which confirmed an engendered social status. In early Christianity the regulatory concern developed from a suspicious recognition of desire's power to the eradication of desire. Foucault (1997 [1981], 183) has demonstrated how a movement has taken place from a 
"penetration model" to an "erection problem." ${ }^{19}$ The shift from a model of penetration to a model of erection is not a changing of the "one-sex model," but an escalation in intensity, a modification in terms of degree, and is as such a radicalisation. In terms of a principle of hierarchy, such a radicalisation implies an extreme concentration of power ... self-power. Although the construction of desire within the operational sphere of a principle of hierarchy also implied an inequal distribution of power, there was at least a relationship to an "other." ${ }^{20}$ With the change from a model of penetration to a model of erection, relationships to "others" change to a relationship to one self. A modified configuration of power ensued. Lovemaking with an "other," although within a superior penetrating versus inferior penetrated relationship, at least opens the possibility of a sharing of power, of a gradual, albeit minute distribution of power. Within a model of erection, power had to be relocated to the site of the "self," where its force had to be that of total exclusion. The construction of desire can only be in terms of its de-construction and must of necessity be driven to the sphere of the negative.

The interior of the body functioned as the site for the construction of desire. Padel (1992, 13) writes: "Splánchna feel. They feel anxiety, fear, grief, and sometimes love and desire." Splánchna is the site where the gods leave their markings from which realities can be read $(1992,14,17)$; the recessive body is associated with consciousness, with knowledge and knowledge deriving from experience. Since they are hidden from sight, the innards they can also harbour the intransparent, the mysterious, the hideous - they can be "dark." Where and how desire is generated from the innards of the body is not always consistent. The liver may be the site of passion and desire (see Padel 1992, 19), but it may also be assigned to the kidneys as Galen did (Brown 1990, 491), or a negative zone, a dark spot in the heart (Brown 1990, 481). Whatever the specific site, desire was seen to erupt from the recessive body and its disruption was so overwhelming as to override the volitional - erection was assigned to the involuntary. A radicalisation of the "one-sex model" would entail a radicalisation of male self-control, the will had to be controlled, had to be fenced and protected. The force with which desire exerts itself as "anti-volitional" contributed to its negative valorization. As it was experienced as a disruptive force, a disturbance of bodily equilibrium and control, early Christianity in its aspirations to absolute control, absolute perfect and controlled manhood, in one way or the other negatively valorized the onset of desire. For early Christianity it is the "disappearance" of the recessive body in its manifestation of desire which is problematised - it was relegated to the dysfunctional.

Desire was consequently related to "dirt"; it became an "unclean pleasure," evil and was regarded as a consequence of the Fall. The myth of Adam and Eve became a handy discursive tool of re-enforcement. The erect penis, hailed, but controlled within the GraecoRoman world became a sign of man's resistance against God (Foucault 1997 [1981], 181).

19 See also Boyarin and Castelli $(2001,362)$ who formulate and interpret in continuity, not only with the specific essay, but also with his insistence on the disclosure of "truth" via the "panopticon": "These are the forces that had shifted the entire self-technology from the classical penetrative model to the erectile model with its concomitant panoptical surveillance of the involuntary movements of concupiscence in the soul and in the flesh.”

20 Foucault (1997 [1982], 191) distinguishes between Clement of Alexandria operating at an earlier time and Cassian. For the former the sexual union of two individuals, as well as the pleasure of the act were requirements for a sexual ethic. For Cassian the sphere moved to the "movements of the body and the mind ... images, feelings, memories, faces in dreams, the spontaneous movements of thoughts, the consenting (or refusing) will, waking and sleeping.

21 See also Foucault (1997 [1982], 191) referring to Cassian's six stages of "unwilling" the presence of the will. 
It signified a failed attempt at man's desire for autonomy from the will of God. For some there was no desire before the Fall. Although Augustine visualised sex before the Fall, it was as something without passion, without the force of desire, without the bodily convulsions, something similar to the impassioned sowing of seeds in an agricultural environment - "Adam," according to Foucault (1997 [1981], 181), "was not involuntarily excited." "Libido" was only produced once Adam resisted the will of God (1997 [1981], 182). Procreation would have happened, but it would have been a voluntary, controlled act (Harlow 1998, 164). Others were a little more positive. Basil of Ancyra, for example, also availed himself of Fall-terminology. Although there was no sex before the Fall, sexual desire was implanted before the Fall and functioned in a kind of pre-remedial sense - it would not have been necessary if there were no Fall. ${ }^{22}$ The negative valorization of the Fall, however, finding expression in a loss of immortality and incorruptibility, necessitated desire, making "immortality by posterity" possible (Shaw 1997, 580). ${ }^{23}$ Although sex, especially "excessive" sexual activity was already associated with the possibility of fatigue, sickness and death from medical discourse originating from Greeks and Romans, early Christians related sex to death, either as obstacle which had to be conquered via procreation, or as retributive consequence of succumbing to desire's temptations (Brown 1990, 483). Allowing for degrees of diversity, desire, in its integration into the Adam and Eve myth, was negatively constructed.

The radicalisation of a "one-sex model" from penetration to the eradication of erection also entailed a radicalised negative valorization of what was regarded as the "inferior other." Instead of a relationship of superior and inferior, the relationship to the "self" entailed on the one hand an objectification of the "self" by means of which the "self" had to function under constant surveillance, but on the other hand, it also casted the "inferior" into a position of enmity, of being an evil threat, a scapegoat for the failure of the "self." 24 Clark $(1998,175)$ finds that "[i]n accounts of the Fall, it is the tendency to load the blame on Eve which makes Adam disappear from sight." Basil of Ancyra required that the female virgin must battle simultaneously on two fronts: on the one hand she has to resist desires and pleasures herself, but on the other hand, she also has to "subdue and negate the power to draw and enslave the male - a power implanted in the female body itself" (Shaw 1997, 582). Given the Graeco-Roman legacy of associating the female body in its "biological" or "natural" constitution with desire, "woman" as embodiment of desire functioned as enemy to male aspirations of self-control.

Whether this intense radicalisation of the one-sex model from a model of penetration to a model of erection could be assigned to early Christianity in its totality is disputable. With typical eloquence Brown $(1990,480)$ refers to the "immense landscape of the Christian church." He indicates that "[w]e are not dealing with the fiery dwarf star of a Greek citystate, but with a veritable galaxy: we are speaking of experiences in Christian communities that stretched from the Rhone Valley to the Zagros Mountains, over a period of four hundred years, preserved for us in documents in at least five major languages..." Several have disclosed a development within early Christianity, but that should not deter from the fact that it was still the "one-sex" regulatory body that regulated early Christian lovemaking, reproducing itself by its self-invented mechanisms. Neither should the

22 For some sex was not seen as natural part of the human condition (Harlow 1998, 163).

23 Shaw $(1997,582)$ also refers to Gregory of Nyssa's treatise "On the making of humanity," produced probably shortly after 380, in which he argues that God must have had a foreknowledge of the Fall and consequently created desire for intercourse.

24 See Foucault (1997 [1982], 195) locating this process within a process of "subjectivation." 
tendency towards a radicalisation of the "one-sex model" be ignored, not only in marriage, but also in the social organisation of the household and the appropriation of its terminology for the construction of mythological discourse. Furthermore, mechanisms intent on reproducing a radicalised version of the "one-sex model" originated in early Christianity and gained in widespread regulatory status.

For Foucault the overarching mechanism of power regulating sexuality in early Christianity was the "pastorate." ${ }^{25}$ The pastorate allows for the emergence of a new social role, by means of which certain individuals solely by virtue of their religious quality function as "pastors" within the early Christian communities (2000 [1982], 333); these people do not define themselves by their social status, their genealogy, nor by their profession and also not by their individual, intellectual or moral qualifications, but simply by their role as caretakers, shepherds to their flock (1999b [1978], 121). Since early Christianity presented itself as a salvation religion, these pastors were responsible for securing salvation for their flock. The primary condition for the operation of the early Christian practice of the pastorate was knowledge of the individual's interior. If desire was to be regulated and controlled by its gradual elimination, the logical point of departure was the recessive body. In order to control the recessive body, the individual was under the obligation to analyse his/her insides and produce the truth concerned with the secrets of the soul. Foucault (1999b [1978], 125) writes: "It [the knowledge of the interior of individuals] means that the pastor ... will have at his disposal means of analysis, of reflection, of detection what happens..." For that reason, "the production of interior truth, the production of subjective truth, is a fundamental element in the practice of the pastor." One of the mechanisms by means of which this interior truth could be established, was the confession. Confession, however, could only be effective if it was exhaustive and happened on a continuous basis. The objective was to establish a technology by means of which thoughts could be controlled and the instigators of desire be thwarted. An intra-scopic regime was established to identify evil and impurity and prevent access to the consciousness of the individual. Truth in the self, located in the recessive body, had to be discovered and disclosed. That which was intransparent in the human will, which may inhabit the quality of temptation, the dark forces of the soul lurking in the deepest recesses of the heart had to be identified and exposed. The de-construction of desire entailed the obligation to produce the "truth" about the self. Knowing yourself, knowing the insides of the body, availing yourself of external assistance to get to know the inside of the body could anticipate the first stirrings of desire, and could prevent its onslaught.

Besides an intra-scopic regime obligating the disclosure of interior truth which gradually became institutionalised through the practices of the pastorate, a dietary regime, regulating the intake of food and drink in terms of quantity and quality, also functioned as mechanism by means of which desire could be so de-constructed as to prevent nocturnal bodily emissions, the appearance of lustful dreams or the invasion of indecent thoughts. Brakke (1995) opens a field of problematisations concerning nocturnal emissions, not only pointing to a particular development from an etiology posing a connection between empirical perception in an awakened condition and dream images, to an etiology of the interiorisation of impurity, but also to the manner in which nocturnal emissions provided a processural site for reflection on the interaction between the male individual body and the social body of the church. The development reached its climax again with Cassian who desired the destruction of an "inside" where defiling thoughts could be formed $(1995,454)$.

25 For elaborations on the notion of "pastoral power" see Foucault (1999b [1978], 121-126; 1999a [1980], 169181; 1997b [1981], 182-187); Boyarin and Castelli (2001, 360-362, 366); Moxnes (2003, 15). 
The close external proximity of belly and genitalia functioned as a popular element in the "belly-topos" widespread in the body rhetoric of antiquity. Eating, drinking and lust were associated, making it possible to locate both gluttony and sexual lust as forms of excessiveness. ${ }^{26}$ From several early Christian writers a dietary regime was prescribed to regulate the influence which the intake of food might have had on the inside of the body and specifically on the instigation of desire. In certain cases the dietary regimes availed themselves of medical discourse and the patriarchal engendered humoural theory, discouraging foodstuffs evaluated as more "moist" and therefore also inclining towards the feminine, thereby entrenching, even via the assumed qualities of food, the female body as symbol of uncontrollability, inclined to the provocation of desire. ${ }^{27}$ In general the advice was to use dry, cooling foodstuffs and the objective was to achieve an "absence of passion" a situation of apatheia. ${ }^{28}$

Marriage is the site where one would have assumed a legitimate expression of desire, especially in a period when concordia, companionship and a more "gentle" relationship was promoted among the upper-class of the Graeco-Roman world. Early Christianity indeed continued the household codes of the Graeco-Roman world and with that also assumed that there was a "natural" hierarchy in which the husband was the dominant, the penetrator and master (see Harlow 1998, 166). This was indeed the site where an early Christian male was entitled to have an erection and seminal emission, but only for purposes of procreation. However, there appears to have been a certain paradoxicality concerning the family. On the one hand, the biological family, propagated by the new interiorised morality, was negatively evaluated, since it was associated with the "flesh" - this was the site for procreation and it was seen as contaminated by the Fall. On the other hand, the negative valorization of the family was moderated since familial rhetoric functioned as reservoir for the structuring of myth, as well as for social, ecclesial structures which developed in early Christianity. ${ }^{29}$ However, it was exactly the use of familial rhetoric which again enabled a radicalisation of phallicism. The authority and power of masculinity were enshrined in the making of a complete patriarchal household. Early Christianity was a cult which made the paterfamilias a god. In doing so they "reinforced the "natural" superiority of the male and his position in the social hierarch" (Harlow 1998, 166). Clack aptly summarises such a process whereby God is made in man's image. She writes $(1995,103)$ : "Replace the word "God" with the word "man" and one is left with the stereotypical picture of what constitutes masculinity in patriarchal society." However, the process is even more dynamic than simply the manufacture of divinity. There is a spiral technology at work, since once the terms "father" has been infused with divinity, it returns with an empowered valorization to its origin in the social structure. The symbolic alliance between Father and father, between Creator and penetrator, radicalises the superiority of manhood. ${ }^{30}$ Furthermore, the

26 See Sandnes (2002) for the rhetorical configuration of the belly-topos in its integration of Pauline material, Jewish dietary laws, Graeco-Roman morality and the exegesis of Patristic writers

27 See also Brakke $(1995,439,441,443,448)$ on Antony the Great, Evagrius Ponticus, Dioscorus and John Cassian. See also earlier Tertullian, De ieiunio 1.1 in his insistence on a dry diet of which the norm should be: "food, unmoistened by flesh, and by any juiciness, and by any kind of specially succulent fruit," nothing with "winey flavour" should be eaten or drunk and one should even abstain from regular bathing. See also Shaw's discussion of Basil of Ancyra's advice to virgins, and the reference to Jerome, relating food, sexual desire and fasting as a mechanism for the suppression of desire (1997, 586, 595); also Sandnes (2002, 220-222 for references to Clement of Alexandria's combination of food, sex and the type of food to be avoided.

28 See Shaw $(1997,591)$ on Basil of Ancyra.

29 Krawiec (2003) concludes that asceticism did not only adhere to an "antifamilial" attitude, but that several instances can be found where "profamilial" tendency functioned as its parallel.

30 See also Harlow $(1998,166)$. 
"divine" household is blessed with a son, but a son conceived without the "loss of control" which renders human beings vulnerable in the throes of conquering desire. As a matter of fact, for someone such as Augustine, the son was born from "immaculate seed," without passion or desire, but whereas everything divine was assigned to his father, both his humanity and mortality were derived from his mother, Mary (Harlow 1998, 165). In a similar vein is the close association between pneuma as essential life-giving ingredient in the semen of men and the Holy Spirit as inseminator of Mary should not be overlooked. ${ }^{31}$ In this household of God the Father, woman, in the person of Mary occupied the peripheral role of being a reproductive container. Retaining her virginity implies her proximity to masculinity.

The making of a mythical household with a Father God, opened the possibility for the production of a social structure highly suspicious of the emerging new morality within the Roman period with its concomitant positive appraisal of marriage. Jacobs (1999) has indicated that the early Christian equivalent of the Greek romance novels, the Apocryphal Acts of the Apostles, functioned to subvert and resist the conjugal concordia of the upperclass elite during the Roman period. Instead of marriage as "happy ending," the conjugal union of companionship is problematised; as a matter of fact, marriage as the setting against which these narrative is located within upper-class morality, but prompted by the constant agonistic motivation of the Graeco-Roman world, it is played off and denigrated when compared with the more superior alternative of the "spiritualised Christian family." However, even in this critique on a particular social level's ethics, it is again the GraecoRoman regulatory body, manifested in the "one-sex model" which called the tune and which is radicalised in the spiritual family. First, the agonistic principle is expressed in the manner how aristocratic partners joined in conjugal union, no longer find it morally acceptable and decide to opt for a superior morality. Second, this superior morality forms part of a configuration of practices which can be expressed in the "desire for virginity." It functioned within a morality, striving for ultimate manhood, for the perfection of the male. For women, this desire for virginity had to be achieved in their de-feminization; female virginity meant becoming male. It meant a return to a pre-Fall condition, the end of the possibility to reproduce, a body regulated not only to abstain from the experience of lovemaking, but also to resist the urge of sexual desire (see Shaw 1997, 590-591; Harlow 1998, 166-167; also Clark 1998, 176-177). For males virginity meant achieving the pinnacle of the social hierarchy. Virginity, sexual abstinence implied the perfection of selfcontrol, such a complete regulation of the recessive body that the onset of desire became an impossibility.

\section{Concluding Remarks}

Foucault has quite correctly formulated the status quo position of the West on sexual desire, when he indicated that in the West "one does not learn how to make love, one does not learn to devote oneself to pleasure, one does not learn how to produce pleasure in others, one does not learn how to maximise, to intensify one's own pleasure through the pleasure of others" (1999, 119). He has indicated that it was not only Christianity who was responsible for a sexual morality which created the big negative and which functioned in the production of docile bodies, but that the sacrifice of the "self" had its antecedents in the

31 That an association between the Holy Spirit and the pneuma of male semen was a probability can, for example, be seen in the fear that nocturnal emissions may leave a man "empty of the Holy Spirit" (Brakke 1995, 426) and also be established as such. 
Graeco-Roman world. This is correct and it was possible to identify a "one-sex model" in different appropriations. There was therefore a definite continuity between early Christianity and its environment. However, early Christianity played a constitutive role in the eradication of sexual pleasure, or erotic love. Erotic love was both radicalised and spiritualised. Both instances protected against the humane vulnerability to which desire expose us, but the protection bordered on the perverse. The language of erotic love as used in the Graeco-Roman world was foisted upon by early Christianity to construct radical positions of power. The recognition of an emerging "other" brought about by the discursive practices of lovemaking, was engulfed by an urgent interest's in the self's salvation, and the specific point of entry for early Christianity was the de-construction of desire. Its deconstructed terminology was infused with a patriarchal power, cultivating shame and guilt in those who challenged the imposition of so-called "truths," consolidating by a verticalisation of lovemaking, thereby entrenching the principle of hierarchy. One can only speculate what could have been if a morality pursuing "how life can become more pleasant for more people" (Eagleton 2004, 5), how a morality built upon pleasure instead of so-called "knowledges of truth," could have won the day.

\section{BIBLIOGRAPHY}

Armstrong, J 2002. Conditions of Love: The Philosophy of Intimacy. London: Penguin Books.

Barthes, R 1978. A Lover's Discourse: Fragments. Translated by R Howard. London: Vintage.

Boyarin, D and Castelli, EA 2001. Introduction: Foucault's The History of Sexuality: The Fourth Volume, or, A Field Left Fallow for Others to Till. Journal of the History of Sexuality 10(3/4):357-374.

Brakke, D 1995. The Problematization of Nocturnal Emissions in Early Christian Syria, Egypt and Gaul. Journal of Early Christian Studies 3(1):419-460.

Brown, P 1990. Bodies and Minds: Sexuality and Renunciation in Early Christianity. Pages 479-493 in Before Sexuality: The Construction of Erotic Experience in the Ancient Greek World. Edited by DM Halperin, JJ Winkler and FI Zeitlin. Princeton: Princeton University Press.

---- 1988. The Body and Society: Men, Women and Sexual Renunciatio in Early Christianity. London and Boston: Faber and Faber.

Butler, J. 2004. Precarious Life: The Powers of Mourning and Violence. London and New York: Verso.

---- 1993. Bodies that Matter. New York: Routledge.

Carson, A 2002. Dirt and Desire: The Phenomenology of Female Pollution. Pages 77-100 in Constructions of the Classical Body. Edited by JI Porter. Ann Arbor: The University of Michigan Press.

1990. Putting Her in Her place: Woman, Dirt, and Desire. Pages 135-169 in Before Sexuality: The Construction of Erotic Experience in the Ancient Greek World. Edited by DM Halperin, JJ Winkler and FI Zeitlin. Princeton: Princeton University Press. 
Clack, B 1995. The Denial of Dualism: Theological Reflections on the Sexual and the Spiritual. Feminist Theology 10(5):102-115.

Clark, G 1998. The Old Adam: the Fathers and the Unmaking of Masculinity. Pages 170182 in Thinking Men: Masculinity and its Self-Representation in the Classical Tradition. Edited by L. Foxhall and J. Salmon. London and New York: Routledge.

Clarke, JR 1998. Looking at Lovemaking: Constructions of Sexuality in Roman Art 100 B.C-A.D. 250. Berkeley and London: University of California Press.

Dean-Jones, L 1994. Women's Bodies in Classical Greek Science. Oxford: Clarendon Press.

Dover, KJ 2003 [1973]. Classical Greek Attitudes to Sexual Behaviour. Pages 114-128 in Sex and Difference in Ancient Greece and Rome. Edited by M Golden and P Toohey. Repr. from Arethusa 6 (1973):59-73.

Eagleton, T 2004. After Theory. London: Penguin Books.

Ely, T 2003 [1891]. The Gods of Greece and Rome. New York: Dover Publications.

Foucault, M 2000. The Subject and Power. Pages 326-348 in Essential Works of Foucault 1954-1984. Vol 3. Michel Foucault: Power. Edited by JD Faubion. Repr. from an appendix to H Dryfus and P Rabinow's Michel Foucault: Beyond Structuralism and Hermeneutics, 1982.

1999a. About the Beginning of the Hermeneutics of the Self. Pages 158-181 in Religion and Culture: Michel Foucault. Edited by JR Carrette. New York:

Routledge. Lecture presented at Dartmouth College, Hanover November 1980, also as Howison lecture at Berkeley, California October 1980. Transcribed and edited by T Keenan and M Blasius respectively. Repr. from Political Theory (21.1:198-227, 1993).

---- 1999b. Sexuality and Power. Pages 115-130 in Religion and Culture: Michel Foucault. Edited by JR Carrette. New York: Routledge. Paper presented at the University of Tokyo. Tokyo 1978. Translated by RA Lynch.

---- 1997a. The Battle for Chastity. Pages 185-197 in Michel Foucault: Essential Works of Foucault 1954-1984. Vol 1. Ethics: Subjectivity and Truth. Translated by R Hurley and others. New York: The New Press. Translated by A Forster 1985. Originally published as 'Le Combat de la chasteté, in Communications (35:1982).

---- 1997b. Sexuality and Solitude. Pages 175-184 in Michel Foucault: Essential Works of Foucault 1954-1984. Vol 1. Ethics: Subjectivity and Truth. Translated by R Hurley and others. New York: The New Press. Repr. from London Review of Books (3.9, 21 May-5 June 1981).

--- $\quad$ 1986. The History of Sexuality. Vol 3. The Care of the Self. Translated by R Hurley. New York: Pantheon Books.

---- 1978. The History of Sexuality. Vol 1. An Introduction. Translated by R Hurley. London: Penguin Books.

Goldhill, S 1995. Foucault's Virginity: An Erotic Fiction and the History of Sexuality. Cambridge: Cambridge University Press.

Halperin, DM 2003 [1990]. The Social Body and the Sexual Body. Pages 131-150 in Sex and Difference in Ancient Greece and Rome. Edited by M Golden and P Toohey. Edinburgh: Edinburgh University Press. 
Halperin, DM, Winkler, JJ and Zeitlin, FI 1990. Introduction. Pages 3-20 in Before Sexuality: The Construction of Erotic Experience in the Ancient Greek World. Edited by DM Halperin, JJ Winkler and FI Zeitlin. Princeton: Princeton University Press.

Harlow, M 1998. In the Name of the Father: Procreation, Paternity and Patriarchy. Pages 155-169 in Thinking Men: Masculinity and its Self-Representation in the Classical Tradition. Edited by L Foxhall and J Salmon. London: Routledge.

Henry, MM 1992. The Edible Woman: Athenaeus's Concept of the Pornographic. Pages 250-268 in Pornography and Representation in Greece and Rome. Edited by A Richlin. Oxford: Oxford University Press.

Holt, PN 1992. Love's Body Anatomized: The Ancient Erotic Handbooks and the Rhetoric of Sexuality. Pages 90-111 in Pornography and Representation in Greece and Rome. Edited by A Richlin. Oxford: Oxford University Press.

Jacobs, AS 1999. A Family Affair: Marriage, Class, and Ethics in the Apocryphal Acts of the Apostles. Journal of Early Christian Studies 7(1):105-138.

Joshel, SR 1992. The Body Female and the Body Politic: Livy’s Lucretia and Verginia. Pages 112-130 in Pornography and Representation in Greece and Rome. Edited by A Richlin. Oxford: Oxford University Press.

Kellum, B 2003 [1997]. Concealing/Revealing: Gender in the Play of Meaning in the Monuments of Augustan Rome. Pages 276-289 in Sex and Difference in Ancient Greece and Rome. Edited by M Golden and P Toohey. Edinburgh: Edinburgh University Press. Repr. from The Roman Cultural Revolution (Cambridge 1997), 158-181. Edited by T Habinek and A Schiesaro.

Konstan, D 2000. "Women, Ethnicity and Power in the Roman Empire." Cited February 2000. Online:http://www.uky.edu/AS/Classics/gender.html.

Krawiec, RA 2003. "From the Womb of the Church": Monastic Families. Journal of Early Christian Studies 11(3):283-307.

Laquer, T 1990. Making Sex: Body and Gender from the Greeks to Freud. Cambridge: Harvard University Press.

Leder, D 1990. The Absent Body. Chicago and London: The University of Chicago Press.

March, J 1998. Dictionary of Classical Mythology. London: Cassell.

Moxnes, H 2003. Asceticism and Christian Identity in Antiquity: A Dialogue with Foucault and Paul. Journal for the Study of the New Testament 26(1):3-29.

Myerowitz, M 1992. The Domestication of Desire: Ovid's Parva Tabella and the Theater of Love. Pages 131-157 in Pornography and Representation in Greece and Rome. Edited by A. Richlin. Oxford: Oxford University Press.

Padel, R 1995. Whom Gods Destroy: Elements of Greek and Tragic Madness. Princeton: Princeton University Press.

--- $\quad$ 1992. In and Out of the Mind: Greek Images of the Tragic Self. Princeton: Princeton University Press.

Perkins, J 1995. The Suffering Self: Pain and Narrative Representation in the Early Christian Era. London and New York: Routledge.

Plinius, G 1969. The Letters of the Younger Pliny. Translated by B Radice. Harmondsworth: Penguin Books. 
Plutarchus, LM 1993. Selected Essays and Dialogues. Translated by D Russell. Oxford: Oxford University Press.

Richlin, A 1992. Introduction. Pages xi-xxiii in Pornography and Representation in Greece and Rome. Edited by A Richlin. Oxford: Oxford University Press.

Salomon, N 1997. Making a World of Difference: Gender, Assymmetry, and the Greek Nude. Pages 197-219 in Naked Truths. Edited by AO Koloski-Ostrow and CL Lyons. London: Routledge.

Sandnes, KO 2002. Belly and Body in the Pauline Epistles. Cambridge: Cambridge University Press.

Shapiro, HA 1992. Eros in love: Pederasty and Pornography in Greece. Pages 53-72 in Pornography and Representation in Greece and Rome. Edited by A Richlin. Oxford: Oxford University Press.

Shaw, TM 1997. Creation, Virginity and Diet in Fourth-Century Christianity: Basil of Ancyra's On the True Purity of Virginity. Gender and History 9(3):579-596.

Stewart, A 1997. Art, Desire, and the Body in Ancient Greece. Cambridge: Cambridge University Press.

Sutton, RF 1992. Pornography and Persuasion on Attic Pottery. Pages 3-35 in Pornography and Representation in Greece and Rome. Edited by A Richlin. Oxford: Oxford University Press.

Veyne, P 1987. The Roman Empire. Pages 5-234 in A History of Private Life: From Pagan Rome to Byzantium. Cambridge and London: The Belknap Press of Harvard University Press.

winkler, JJ 1990. The Constraints of Desire: The Anthropology of Sex and Gender in Ancient Greece. New York and London: Routledge

Zeitlin, FI 2002. Reflections on Erotic Desire in Archaic and Classical Greece. Pages 50-76 in Constructions of the Classical Body. Edited by JI Porter. Ann Arbor: The University of Michigan Press. 